\title{
PENGARUH MEDIA AUDIO VISUAL DENGAN PENDEKATAN SAINTIFIK TERHADAP HASIL BELAJAR SISWA MATERI SISTEM PENCERNAAN MANUSIA SISWA KELAS XI SMA NEGERI 2 KABUPATEN SORONG
}

\section{IDAYATI RUMAKWAI}

\author{
Prodi Biologi Universitas Pendidikan Muhammadiyah (UNIMUDA) Sorong
}

\begin{abstract}
ABSTRAK
Tujuan penelitian dilatar belakangi dengan menciptakan kondisi tercapainya hasil konsep keilmuan biologi dengan menggunakan media, untuk mengetahui kemampuan siswa dalam menerima materi sistem pencernaan manusia menggunakan media audio visual dengan pendekatan saintifik. Metode penelitian yang digunakan dalam penelitian ini adalah penelitian kuantitatif dengan satu kelas eksperimen. Bentuk ekperimen dalam penelitian ini adalah Quasi Eksperimen pada jenis Non Equivalent Posstest Only Control Group Design dengan maksud hanya hanya mengambil tes akhir tanpa menggunakan tes awal. Populasi dalam penelitian ini adalah seluruh peserta didik kelas XI di SMA Negeri 2 Kabupaten Sorong dan sampel sampel yang digunakan adalah kelas XI IPA I sebagai kelas eksperimen. Hasil tes siswa berupa nilai rata-rata 77,83 yang kemudian dianalisis dengan rumus uji regresi linier sederhana menggunakan SPSS versi 20 sehingga diperoleh nilai signifikan 0,890 dengan probalitas 0,05. Hasil perhitungan tesebut menunjukkan bahwa signifikansi 0,890>0,05 sehingga dapat disimpulkan ada pengaruh media audio visual dengan pendekatan saintifik terhadap hasil belajar siswa kelas XI IPA I SMA Negeri 2 Kabupaten Sorong.
\end{abstract}

Kata Kunci : media audio visual, pendekatan saintifik, hasil belajar.

\section{PENDAHULUAN}

Belajar adalah suatu proses kompleks yang terjadi pada semua orang dan berlangsung seumur hidup, sejak dia masih hidup hingga ke liang lahat nanti. Salah satu pertanda bahwa seseorang telah belajar adalah adanya perubahan tingkah laku dalam dirinya. Perubahan tingkah laku tersebut menyangkut baik perubahan yang bersifat pengetahuan (kognitif) dan keterampilan (psikomotor) maupun yang menyangkut nilai dan sikap (afektif) (Sadiman, dkk. 2012).

Perkembangan ilmu pengetahuan dan semakin mendorong upaya-upaya pembaruan dalam pemanfaatan hasil-hasil teknologi dalam proses belajar. Para guru dituntut agar mampu meggunakan alat-alat yang dapat disediakan oleh sekolah, dan tidak tertutup kemungkinan bahwa alatalat tersebut sesuai dengan perkembangan dan tuntunan zaman. Disamping mampu menggunakan alat-alat yang tersedia, guru juga dituntut dapat mengembangkan keterampilan membuat media pembelajaran yang akan digunakannya apabila media tersebut belum tersedia (Arsyad, 2013).

Melalui pengamatan lapangan yang telah dilakukan, guru masih kurang dalam pemanfaatan media pembelajaran di kelas. Pembelajaran dengan menggunakan metode ceramah masih diterapkan oleh guru sehingga siswa sebagai objek bersifat pasif, hanya mendengarkan, menghafal serta menyimak pengetahuan yang ditransfer dari guru. Guru cenderung hanya menggunakan buku pelajaran yang ada sebagai satu-satunya sumber belajar. (sumber, Sekolah SMA Negeri 2 Kabupaten Srong).

Arsyad (2013) menyatakan bahwa pemakaian media pembelajaran dalam proses pembelajaran dapat membangkitkan keinginan belajar, minat yang baru, membangkitkan motivasi, merangsangan kegiatan belajar, dan bahkan membawa pengaruh-pengaruh psikologi terhadap siswa.

Berdasarkan hasil wawancara terhadap guru SMA Negeri 2 Kabupaten Sorong diperoleh informasi bahwa penggunaan media audio visual jarang digunakan serta hasil belajar biologi pada materi _ltern pencernaan pada beberapa siswa masih rendah. Hal ini didukung oleh daftar nilai beberapa kelas XI pada SMA Negeri 2 Kabupaten Sorong jika dibandingkan dengan Kriteria Ketuntasan Minimal (KKM) yang telah ditetapkan yaitu 75. Nilai Ulangan Semester Ganjil Kelas XI SMA Negeri 2 Kabupaten Sorong Tahun Ajaran 2017/2018, kelas XI IPA I ratarata nilai ulangan semester ganjil 67, kelas XI IPA II rata-rata nilai ulangan semester ganjil 50, kelas XI IPA III rata-rata nilai ulangan semester ganjil. (Sumber, Guru mata pelajaran biologi kelas XI SMA N 2 Kab Sorong). Rata-rata nilai ulangan semester ganjil siswa kelas XI SMA Negeri 2 Kabupayen Sorong belum mencapai hasil yang sesuai dengan harapan. Nilai yang didapatkan berkisar antara angka 60-30, sedangkan_lternat ketuntasan minimal ditetapkan sekolah yaitu 75 .

Hasil wawancara dengan beberapa siswa SMA Negeri 2 Kabupaten Sorong diketahui juga bahwa dalam mengajar, guru lebih banyak berceramah dan memberikan tugas-tugas yang ada pada buku sumber. Akibat dari pembelajaran tersebut siswa menjadi kurang memahami materi yang dipelajari. Hal ini akan mengakibatkan siswa mudah melupakan materi yang telah dipelajari dan pembelajaran menjadi kurang menyenangkan khususnya pada mata pelajaran Biologi.

Pengaruh penggunaan media audio visual dengan pendekatan saintifik dapat diterapkan sebagai 
solusi untuk memperbaiki hasil dan proses pembelajaran biologi pada materi_ltern pencernaan. Pendekatan saintifik juga lebih menekankan pada ranah afektif diharapkan dapat mengembangkan karakter positif dalam diri siswa, serta untuk membentuk kemampuan siswa dalam menyelesaikan suatu masalah secara sistematik. Berdasarkan hasil penelitian Ernawati dkk, (2015) mampu meningkatkan hasil belajar siswa, dengan judul Pengaruh Penerapan Pendekatan Saintifik Berbantu Media Audio Visual Terhadap Hasil Belajar Siswa Kelas V Tema Ekosistem Di SDN Ajung 03 Jember.

\section{METODE PENELITIAN}

Jenis penelitian yang digunakan adalah penelitian eksperimen semu (Quasi Eksperimen). Arikunto (2010) berpendapat bahwa penelitian eksperimen semu adalah jenis penelitian yang bertujuan untuk memperoleh informasi dari eksperimen berdasarkan perlakuan (treatmen) terhadap suatu unit percobaan dalam batas-batas desain yang ditetapkan pada kelas eksperimen.

Desain penelitian yang digunakan adalah posttest control group design. Dalam desain ini kelompok eksperimen maupun kelompok kontrol tidak dipilih secara random (Sugiyono, 2015).

\begin{tabular}{|c|c|c|}
\hline No & $\begin{array}{c}\text { Nilai } \\
\text { tes }\end{array}$ & Jumlah Siswa \\
\hline 1 & $51-60$ & 7 \\
\hline 2 & $61-70$ & 9 \\
\hline 3 & $71-80$ & 10 \\
\hline 4 & $81-90$ & 7 \\
\hline 5 & $91-100$ & 4 \\
\hline Jumlah & 37 & \\
\hline \multicolumn{4}{|c|}{ Berdasarkan tabel hasil posttest Mata }
\end{tabular}

Pelajaran Biologi Materi Sistem Pencernaan Manusia Kelas XI SMA Negeri 2 Kabupaten Sorong dengan pembelajaran menggunakan media audio visual dengan pendekatan saintifik hasil belajara siswa yang memperoleh nilai 51-60 $=7$ Siswa, 61-70 $=9$ siswa, $71-80=10$ siswa, $81-90=7$ siswa, dan 91-100 = 4 Berdasarkan hasil gambar diagram 4.1 maka dapat simpulkan bahwa jumlah siswa yang mendapatkan nilai $51-60=7$ Siswa, 61-70 $=9$ siswa, 71-80 $=10$ siswa, $81-90=7$ siswa, dan 91-100 $=4$ siswa.

\begin{tabular}{|l|l|l|}
\hline No & Keterangan & Hasil \\
\hline 1 & Jumlah siswa & 37 \\
\hline 2 & Nilai tertinggi & 100 \\
\hline 3 & Nilai terendah & 60 \\
\hline 4 & Jumlah nilai post test & 2.880 \\
\hline 5 & Nilai Rata-Rata Posttest & 77,83 \\
\hline 6 & $\begin{array}{l}\text { Jumlah siswa yang tuntas } \\
\text { belajar }\end{array}$ & 24 \\
\hline
\end{tabular}

Penelitian ini merupakan penelitian eksperimental yang bertujuan untuk mengetahui adakah pengaruh media audio visual dengan pendekatan saintifik terhadap hasil belajar siswa kelas XI IPA I dengan Materi Sistem Pencarnaan Manusia di kelas XI IPA I SMA Negeri 2 Kabupaten Sorong. Penelitian ini di lakukan di SMA Negeri 2 Kabupaten Sorong dengan
Dalam penelitian ini menggunakan dua variabel yaitu variabel bebas yaitu media audio visual dengan pendekatan saintifik, variabel terikat yaitu hasil belajar siswa. Setelah eksperimen menggunakan media audio visual dengan pendekatan saintifik siswa diberikan posttest untuk mengetahui hasil belajar siswa. Populasi dalam penelitian ini adalah seluruh peserta didik kelas XI SMA Negeri 2 Kabupaten Sorong. Sampel yang digunakan dalam penelitian ini adalah kelas XI IPA II SMA Negeri 2 Kabupaten Sorong. Pada penelitian ini, soal tes yang digunakan adalah pilihan ganda sebanyak 40 soal. Uji Regresi sederhana digunakan dalam penelitian ini hubungan fungsional ataupun kausal satu variabel independen dengan satu variabel dependen.

\section{HASIL DAN PEMBAHASAN}

tujuan penelitian ini adalah untuk mengetahui pengaruh hasil belajar siswa kelas XI SMA Negeri 2 Kabupaten Sorong pada pembelajaran Biologi tentang _ltern pencernaan manusia dengan menggunakan media audio visual dan pendekatan saintifik.

Berdasarkan tes yang telah diberikan kepada siswa kelas XI IPA I SMA Negeri 2 Kabupaten Sorong. Hasil Belajar yang diperoleh dengan menggunakan posstest berupa soal pilihan ganda dapat dilihat pada tabel 4.1.

siswa dengan jumlah siswa 37 . Ketuntasan belajar pada posttest di kelas XI IPA I setelah proses belajara mengajar menggunakan media audio visual dengan pendekatan saintifik dapat di gambarkan pada diagram 4.1 .

Gambar 4.1. Hasil kelas tes XI IPA I

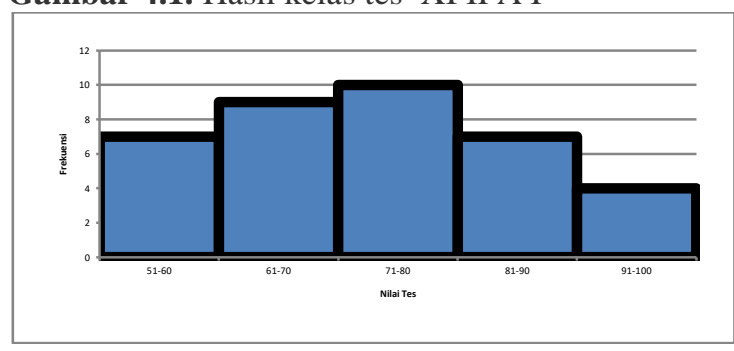

Hasil perhitungan nilai posttest kelas eksperimen yang didapat selama penelitian ini dapat dilihat pada tabel berikut.

\begin{tabular}{|l|l|l|}
\hline 7 & $\begin{array}{l}\text { Persentase ketuntasan } \\
\text { belajar }\end{array}$ & $65 \%$ \\
\hline 8 & $\begin{array}{l}\text { Jumlah siswa yang belum } \\
\text { tuntas belajar }\end{array}$ & 13 \\
\hline 9 & $\begin{array}{l}\text { Persentase belum tuntas } \\
\text { belajar }\end{array}$ & $35 \%$ \\
\hline
\end{tabular}

penarapan media audio visual dengan pendekatan saintifik yaitu menerapkan metode diskusi Tanya jawab dan penugasan.

Penerapan penggunaan media audio visual dengan pendekatan saintifik bertujuan membantu siswa dalam proses pembelajaran guna pempermuda siswa dalam memperoleh informasi pelajaran. Nilai 
rata-rata siswa sesudah di beri perlakuan 77,83 adalah 2.880 secara stastistik ada pengaruh yang signifisikan terhadap hasil belajar siswa.

Kegiatan selanjutnya melakukan uji regresi untuk menguji $\mathrm{H} 1$ Atau $\mathrm{H} 0$ yang akan di terima dari hasil uji stastistik independen sampel test menggunakan program SPSS Versi 20 di peroleh bawah hasil siknifikan 0,890>0,05 sehingga dapat di simpulkan bahwa ada pengaruh media audio visual dengan pendekatan saintifik terhadap hasil belajar siswa. Artinya H1 yang menyatakan ada pengaruh penggunaan media audio visual dengan pendekatan sentifik terhadap hasil belaja siswa pada pelajaran biologi materi system pencernaan manusia kelas XI SMA Negeri 2 Kabupaten Sorong.

Berdasarkan analisis data yang di lakukan oleh penelitian dapat di ketahui bahwa terdapat hasil yang siknifikan terhadap hasil belajar siswa dengan mengunakan media audio visial dengan pendekatan saintifik. Hal ini sesuai yang di jelaskan oleh Munir (2010) yang mengemukakan bahwa" kelengkapan media dalam teknologi multimedia melibatkan

\section{DAFTAR PUSTAKA}

Arsyat. (2013). Penggunaan Media Audio Visual Terhadap Hasil Belajar Siswa. Fakultas Keguruan Dan Ilmu Pendidikan Universitas Lampung .

Sanjaya. (2010). Pengaruh Pendekatan Saintifik Berbantuan Media Audio Visual Terhadap Hasil Belajar Ipasiswa Sd Kelas V . E-Journal Pgsd Universitas Pendidikan Ganesha Jurusan Pgsd .

Nur. (2013). Penggunaan Pendekatan Saintifik Melalui Model Pembelajaran Video Session, Poster Session Dan Teknologi Informasi Dalam pendayagunaan seluruh panca indera sehingga daya imajinasi, kreatifitas, fantasi,emosi pesertadidik berkembang kearah yang lebih baik".

\section{KESIMPULAN}

Berdasarkan hasil analisis data dan pembahasan terdapat hasil penelitian dapat di simpulkan bahwa ada pengaruh signifikan penggunaan media audio visual dengan pendekatan saintifik terhafap hasil belajar siswa pada pelajaran biologi materi_ltern pencernaan manusia kelas XI SMA Negeri 2 Kabupaten Sorong. Hasil perhitungan nilai postes kelas esperimen dibuktikan dengan hasil analisis data yang menujukan bahwa hasil pengujian menggunakan uji regresi di peroleh taraf signifikan 0,890>0,05 sehingga $\mathrm{H} 0$ ditolak dan HI diterima hasil peritungan keefektifan penggunaan media audio visual dengan pendekatan saintifik terhadap hasil belajar siswa sebesar $0,024 \%$, hal ini meiliki arti bahwa pencapaian hasil belajar siswa kelas XI IPA 1 menggunakan media audio visual dengan pendekatan saintifik efektif sebesar $24 \%$.

Pembelajaran Pai

Http://Usu.Ac.Id/Public/Content/Files/Sisdiknas. $P d f$.

Sugiyono. (2015). Metode Penelitian Dan Pengembangan. Bandung: $\mathrm{Cv}$ Alvabeta.

Munir. (2010). Pengaruh Penggunaan Media AudioVisual Terhadap Hasil Belajar Siswa Kelas V Materi Keragaman Kenampakan Alam Dan Buatan Indonesia. Jurusan Pendidikan Guru Sekolah Dasar, Fakultas Ilmu Pendidikan, Universitas Pendidikan Indonesia . 